\title{
Haematological characteristics of Brazilian Teleosts. III. Parameters of the hybrid tambacu (Piaractus mesopotamicus Holmberg x Colossoma macropomum Cuvier) (Osteichthyes, Characidae)
}

\author{
Marcos Tavares-Dias ${ }^{1}$ \\ Sérgio H.C. Schalch ${ }^{1}$ \\ Maurício L. Martins ${ }^{1}$ \\ Eduardo M. Onaka ${ }^{1}$ \\ Flávio R. Moraes ${ }^{1,2}$
}

\begin{abstract}
Fifty six specimens of the hybrid "tambacu" (Piaractus mesopotamicus Holmberg, 1887 male x Colossoma macropomum Cuvier, 1818 female) were collected from fishfarm of Guariba, São Paulo, to evaluate their haematology. Fishes presented 400.0 to $3,100.0 \mathrm{~g}$ total weight and 20.0 to $52.0 \mathrm{~cm}$ total length. Haemoglobin, haematocrit, mean corpuscular haemoglobin content (MCHC) and percentage of defense blood cells including leucocytes and thrombocytes, were studied. Statistical analysis showed positive correlation $(\mathrm{P}<0.01)$ between haematocrit, $\mathrm{MCHC}$ and haemoglobin rate. Nevertheless, thrombocytes and lymphocytes showed negative correlation $(\mathrm{P}<0.01)$.

KEY WORDS. tambacu hybrid, haematology, haemoglobin, haematocrit, leucocytes, thrombocytes
\end{abstract}

Brazilian aquaculture initiated with the Northeast settlement Netherland colonizers. Still, the culture of native species was limited for a long period due to the lack of technology of fry production (ZANIBONI-FILHO 1997). Recent development of technics to increase the economy of fishfarming was responsible for the investments on some native species like the "tambaqui" Colossoma macropomum Cuvier, 1818 and the "pacu" Piaractus mesopotamicus Holmberg, 1887 (CASTAGNOLLI 1992). Environmental factors bring about limitations in the culture of native species. However, hybridization was a solution for this problem, culminating with the hybrid "tambacu". "Tambacu" has a great economical importance but little is known about their physiology and haematology. Standardization of methods is important for determination of the effects of diet, diseases, handling stress and other environmental factors upon fishes (SILVEIRA \& RigORES 1989).

Recent reports on haematological parameters of intensively cultivated $P$. mesopotamicus showed similar values when compared to C. macropomum (TAVARES-DiAS et al. 1998, 1999a,b).

1) Centro de Aqüicultura, Universidade Estadual Paulista. Via de Acesso Professor Paulo Donato Castellane, 14870-000 Jaboticabal, São Paulo, Brasil.

2) Departamento de Patologia Veterinária, Universidade Estadual Paulista. Via de Acesso Professor Paulo Donato Castellane, 14870-000 Jaboticabal, São Paulo, Brasil. 
In the present work, haematological parameters of tambacu hybrids reared in the commercial fishfarm, mean values of haematocrit, haemoglobin, mean corpuscular haemoglobin concentration, differential count of defense cells (leucocytes and thrombocytes) were evaluated.

\section{MATERIAL AND METHODS}

With the aid of line and hook, 56 juvenile specimens of the hybrid "tambacu" (Piaractus mesopotamicus $\mathrm{x}$ Colossoma macropomum) were collected between May to October 1997. Fish were reared in a $13,000 \mathrm{~m}^{2}$ reservoir, in Guariba, State of São Paulo, Brazil ( $21^{\circ} 19^{\prime \prime} 17^{\prime} \mathrm{S}$ and $\left.48^{\circ} 12^{\prime \prime} 37,8^{\prime} \mathrm{W}\right)$, and were fed with commercial food. Fish were anaesthetized with 1:15 benzocaine solution for collection of 1.0 $\mathrm{ml}$ blood from the caudal vein with syringes containing EDTA (10\%) for the following analyses: haematocrit (Ht) according to GOLDENFARB et al. (1971), haemoglobin (Hb) according to COLLIER (1944) and mean corpuscular haemoglobin concentration (MCHC) according to WINTROBE (1934). Blood smears were stained by ROSENFELD (1947) method for the differential counts of the defense cells. During the experiment, water $\mathrm{pH}$ was maintained at $7.1 \pm 0.2$; electric conductivity at $507.0 \pm 140.0 \mu \mathrm{S} / \mathrm{cm}$ and mean water temperature at $21.8 \pm 1.8^{\circ} \mathrm{C}$. According to BANZATO \& KRONKA (1995) the results were analyzed by the linear regression and $\mathrm{F}$ test, to the $1 \%$ probability level. Necroscopical examination was performed to confirm the state of health of the studied animals.

\section{RESULTS}

\section{Erythrocyte parameters}

Haematological parameters of the red blood cells of "tambacu" are shown in table I. Linear regression analysis showed significant positive correlation $(\mathrm{P}<0.05)$ between haematocrit and $\mathrm{MCHC}$ with the haemoglobin concentration (Fig. 1) as for the following equations: $\mathrm{Ht}=20.451+1.5538(\mathrm{Hb}) ; r=0.75$ and $\mathrm{MCHC}=14.719+1.3155(\mathrm{Hb}) ; r=0.75$.

Table I. Haematological parameters of the hybrid tambacu. The data are expressed in mean values \pm standard deviation and amplitude variation $(A x)$ in 56 specimens.

\begin{tabular}{|c|c|c|c|}
\hline Parameters & Mean values & & $A x$ \\
\hline Weight (g) & $1,007.5 \pm 554.5$ & 400.0 & $-3,100.0$ \\
\hline Length $(\mathrm{cm})$ & $37.9 \pm 6.2$ & 20.0 & - 42.0 \\
\hline Heamoglobin (g/dL) & $12.7 \pm 3.7$ & 5.1 & 18.9 \\
\hline Hematocrit (\%) & $40.2 \pm 7.7$ & 20.0 & 57.0 \\
\hline $\mathrm{MCHC}(\mathrm{g} / \mathrm{dL})$ & $31.5 \pm 6.5$ & 19.7 & 44.0 \\
\hline
\end{tabular}

\section{Morphological characteristics of defense blood cells}

Blood smears of "tambacu" revealed the presence of thrombocytes, neutrophils, lymphocytes, monocytes, special granulocitic cells and eosinophils in circulating blood. Special granulocitic cells (SGC) were spherical with abundant cytoplasm, rich in ligth translucent and spherical granulation and uniformly distributed. The nucleus of this cell was small, with gross chromatin without nucleoli (Fig. 2A). Monocytes showed spherical shape with basophilic vacuolated or not vacuolated 


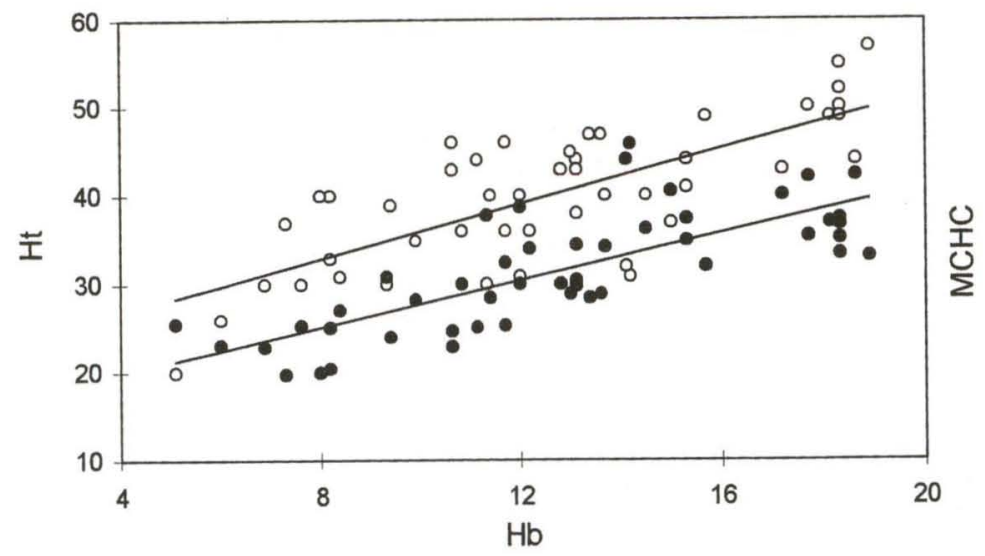

Fig. 1. Relation between haematocrit $(O)$ and mean corpuscular haemoglobin concentration (-) with haemoglobin in 56 specimens of "tambacu".

cytoplasm. The nucleus was frequently eccentric, elongated, sometimes spherical (Fig. 2B,E). Thrombocytes were elongated spindle-shaped cells, with acidophilic cytoplasm without granulation. The nucleus were elongated showing a spindle-shaped and deeply stained structure (Fig. 2C). Eosinophils were spherical and small when compared with the other granulocitic cells presenting an acidophilic cytoplasm rich in eosinophilic granulation. Their round nucleus occupie a great proportion of the cell (Fig. 2C). Lymphocytes were predominantly spherical with variable size showing a deeply basophilic cytoplasm without granulation and nucleus slightly shaped like the human kidney with dense chromatin. Their relation with the cytoplasm was narrow (Fig. 2C). Neutrophils were round-shaped cell with acidophilic cytoplasm with fine granulation occupying a great proportion of the cytoplasm. Their nucleus was segmented, rod-shaped and in eccentric position (Fig. 2D).

Mean values and change intervals of differential counts are shown in table II. Thrombocytes and lymphocytes were the most frequently observed cells in circulating blood of "tambacu": $66.8 \pm 12.5 \%$ and $21.0 \pm 10.6 \%$, respectively. Linear regression showed negative correlation $(\mathrm{P}>0.01)$ between the percentage of such cells (Fig. 3) indicating that an increase in thrombocyte was responsible for a decrease in lymphocyte number. This was demonstrated by the following equation: Lymphocyte $=-0.6301$ (Thrombocyte) $+63.077 ; r=0,74$.

Statistical analysis of the other defense cells showed no significant correlation.

Table II. Percentage of defense blood cells in the hybrid tambacu. The data are expressed in mean values \pm standard deviation and change amplitude $(\mathrm{Ax})$ in 56 specimens.

\begin{tabular}{lrr}
\hline \multicolumn{1}{c}{ Parameters $(\%)$} & Mean values & Ax \\
\hline Thrombocytes & $66.8 \pm 12.5$ & $44.0-91.0$ \\
Lymphocytes & $21.0 \pm 10.6$ & $1.0-43.0$ \\
Neutrophils & $6.4 \pm 6.2$ & $0.0-24.0$ \\
Monocytes & $3.1 \pm 3.3$ & $0.0-14.0$ \\
Eosinophils & $1.5 \pm 2.4$ & $0.0-13.0$ \\
SGC & $1.2 \pm 1.8$ & $0.0-11.0$ \\
\hline
\end{tabular}




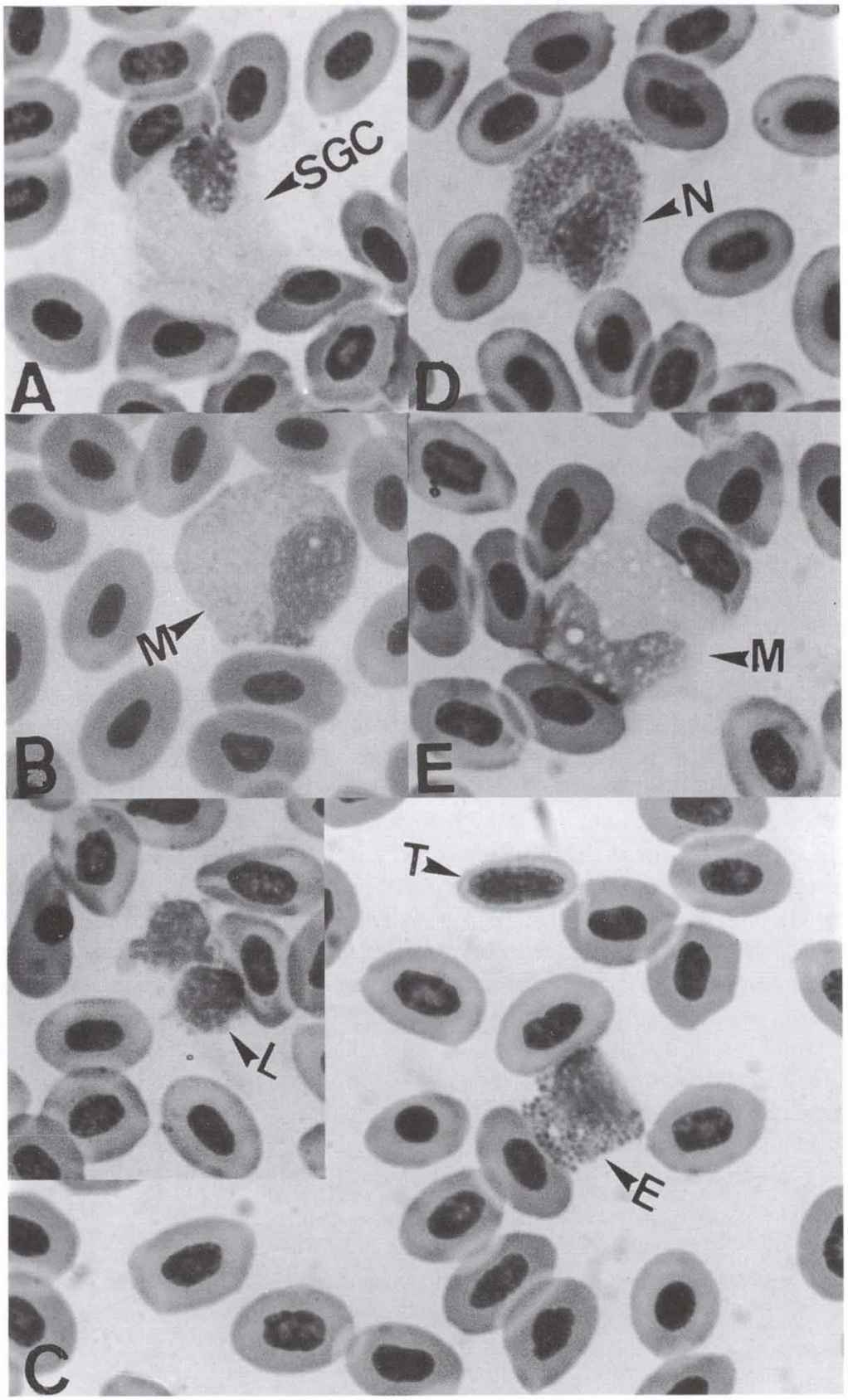

Fig. 2. Defense blood cells of the hybrid tambacu. (A) Special granulocitc cell (SGC); (B) monocyte (M); (C) lymphocyte (L), thrombocyte (T) and eosinophil (E); (D) neuthrophil (N) and (E) monocyte (M). Stained with ROSENFELD (1947). 


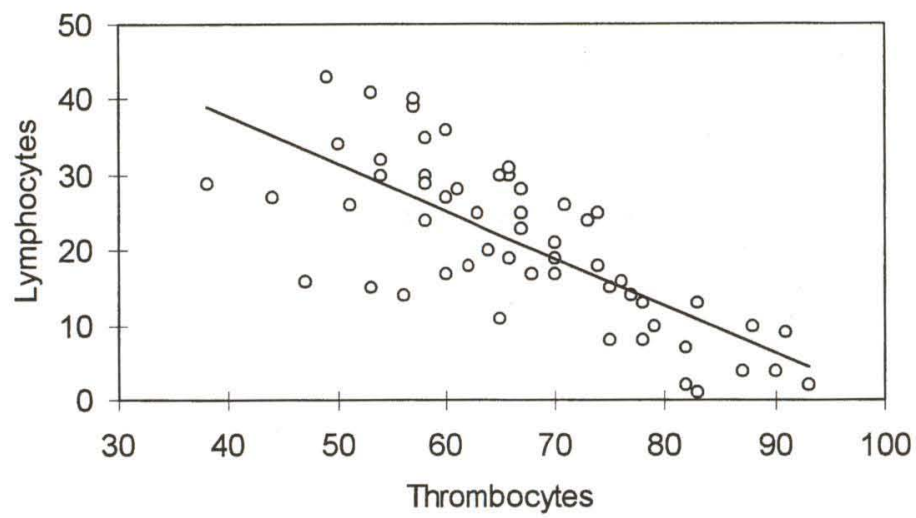

Fig. 3. Relation between percentage of thrombocytes and lymphocytes in 56 specimens of "tambacu".

\section{DISCUSSION AND CONCLUSIONS}

Organic factors such as weight (LARSSON et al. 1976; RANZANI-PAIVA 1991) or length (PITOMBEIRA et al. 1968; LARSSON et al. 1976; RANZANI-PAIVA 1991) may be responsible for the morphological and quantitative changes in the blood parameters. Mean values of haematocrit, haemoglobin and MCHC of "tambacu" showed increase when compared to C. macropomum (TAVARES-DIAS et al. 1998; RANZANI-PAIVA et al. 1998/1999) and P. mesopotamicus (RANZANI-PAIVA et al. 1998/1999; TAVARES-DiAs et al. 1999a). Nevertheless, it must be considered that fishes studied in the present work have a bigger size.

The correlation between weight and haematocrit was demonstrated in $\mathrm{On-}$ corhynchus mykiss Walbaum, 1792 and Dicentrarchus labrax Linnaeus, 1758 (GARCIA et al. 1992); between weight, haematocrit and haemoglobin in O. mykiss (MARTÍNEZ et al. 1994); between length, haemoglobin and erythrocyte count in Salmo gairdneri Richardson,1836 (Salmonidae) (LowE-JINDE \& NIIMI 1983); between haemoglobin and haematocrit in C. macropomum (TAVARES-DIAS et al. 1998). In the present paper, haemoglobin presented positive correlation with haematocrit and MCHC in blood of "tambacu". The same correlation was related in bluegill, Lepomis macrochirus Rafinesque (MURRAY 1984) and Clarias isheriensis Sydenham (Clariidae) (KORI-SIAKPERE 1985).

Defense blood cells identified in "tambacu" were morphologically similar to the ones described in Hoplias malabaricus Bloch, 1794 (CAMARGO et al. 1986/1987), Cyprinus carpio Linnaeus, 1758 (RANZANI-PAIVA et al. 1987), Brycon sp. (Characidae) (RANZANI-PAIVA 1996), P. mesopotamicus (TAVARES-DIAS et al. 1999a) and C. macropomum (TAVARES-DiAs et al. 1999b). The low presence of eosinophils in the blood of "tambacu" was observed. The same result was related in Prochilodus scrofa Steindachner, 1881(RAnZANi-PAIVA et al. 1998/1999). However, higher eosinophils values was described in P. mesopotamicus and C. macropomum (RANZANI-PAIVA et al. 1998/1999).

Thrombocytes were the predominant defense blood cells in the smears of "tambacu" followed by lymphocytes, neutrophils, monocytes, eosinophils and special 
granulocitic cells. Elevated percentage of thrombocytes was described in bluegill. (MURRAY 1984), in Gudusia chapra Hamilton, 1822 (CHONDAR 1982), Sarotherodon melanotheron Ruppel, 1852 (LEA MASTER et al. 1990), Oreochromis niloticus Linnaeus, 1758 (TAVARES-Dias \& FAustino 1998), P. mesopotamicus (TAVARES-Dias et al. 1999a,c,d), C. macropomum (TAVARES-DiAs et al. 1999b), Leporinus macrocephalus Garavello \& Britski, 1988 (TAVARES-DiAS et al. 1999d) and Brycon cephalus Günther, 1869 (Characidae) (TAVARES-DiAs et al. 1999e) when compared to the others cells. On the other hand, lymphocytes number is higher than thrombocytes in C. carpio (HINES \& YASHOUV 1970) and O. mykiss (Houston et al. 1996).

Thrombocytes function in fish is questionable (LOPES et al. 1997). In birds, reptiles (GARCIA-NAVARRO \& PACHALY 1994; PENHA et al. 1996), amphibians and fish the involvement of thrombocytes in coagulation is known as their analogy with platelets (PenHA et al. 1996; TAVARES-Dias et al. 1999d). PENHA et al. (1996) demonstrated thrombocytes activity in bullfrog (Rana catesbeiana Shaw, 1802) injected with colloidal carbon. In spite of leucocitic cells, their importance in inflammatory exsudate and phagocitosis indicate an-organic defense relation (GRECCHI et al. 1980; ISHIDA et al. 1985; KAJIGAYA et al. 1985; SUZUKI 1986; DIAS \& SinHORINI 1991, 1992; MATUSHIMA \& MARIANO 1996). On the other hand, some authors include, erroneously, thrombocytes in the differential count of leucocytes (WeInBERG et al. 1973; RAIZADA \& SingH 1981; ChONDAR 1982; MurRAy 1984; LEA MASTER et al. 1990; Houston et al. 1996).

In teleost the exact function of each kind of defense blood cells is obscure. In the circulating blood eosinophils occurs in small number but abundant in the intestinal submucosa, in the peritoneal liquid, mesentery and gills (RANZANI-PAIVA 1991). In Argulus sp. (Crustacea) infested C. carpio a great number of leucocytes have been reported (RANZANI-PAIVA et al. 1987). RANZANI-PAIVA et al. (1987) observed the frequency of special granulocitic cells and eosinophils in parasitized fish. Infestation with Argulus sp. decreased thrombocytes percentage of $P$. mesopotamicus and increased monocytes and special granulocitic cells percentage (TAVARES-DIAS et al. 1999c). In the present work, "tambacu" did not show parasites but special granulocitic cells and eosinophils were present. Further studies must be carried out with this hybrid to determine haematological parameters of parasitized "tambacu" that is one of the most cultivated fish in Brazilian fishfarm.

\section{REFERENCES}

Banzato, D.A. \& S.N. KronKa. 1995. Experimentação agrícola. Jaboticabal, FUNEP, $3^{a}$ ed., 247p.

Camargo, F.T.; J.R.V. Costa; A.C. Souza Cruz; W. Rocha \& V.V Vignoli. 1986/1987. Estudo das séries hematológicas da traíra Hoplias malabaricus (Pisces - Teleostea). Rev. Esc. Farm. Odont. Alfenas 9: 63-69.

CAstagnolli, N. 1992. Piscicultura de água doce. Jaboticabal, FUNEP, 189p.

ChOndar, S.L. 1982. The haematology of Gudusia chapra (Pisces: Clupeidae). Jour. Inland Fish. Soc. India. $14(1): 1-10$.

Collier, H.B. 1944. The standardization of blood haemoglobin determinations. Can. Med. Ass. Jour. 50: $550-552$.

DIAS, J.L.C. \& I.L. SINHORINI. 1991. Qualitative evaluation of the inflammatory response modulated by temperature in tadpoles of Rana catesbeiana. Ciênc. Cult 43: 304-6. 
1992. Aspectos ultra-estruturais de células inflamatórias de girinos de Rana catesbeiana (rã-touro-gigante). Ciênc. Cult. 44 (Supl.): 730.

García, M.P.; G. Echevarria; F.J. MartíneZ\& S. Zamora. 1992. Influence of blood sample collections on the haematocrit value of two teleosts: rainbow trout (Oncorhyncus mykiss) and European sea bass (Dicentrarchus labrax L.). Comp. Biochem. Physiol. 101A: 733-736.

Garcia-Navarro, C.E. \& J.R. Pachaly. 1994. Manual de hematologia veterinária. São Paulo, Livraria Varela, 169p.

Goldenfarb, P.B.; F.P. Bowyer; E. Hall \& E. Brosious. 1971. Reproducibility in the hematology laboratory: the microhematocrit determination. Amer. Jour. Clin. Path. 56: 35-39.

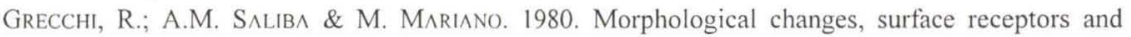
phagocytic potencial of fowl mononuclear phagocytes and trombocytes in vivo and in vitro. Jour. Pathol. 130: 23-31.

HINES, R. \& A. YASHOUV. 1970. Differential leukocyte counts and total leukocyte and erythrocyte counts for same normal israeli mirror carp. Bamidgeh 22: 106-113.

Houston, A.H.; N. Dobric \& R. KAHURANANGA. 1996. The nature of hematological response in fish. Fish Physiol. Biochem. 15 (4): 339-347.

Ishida, Y.; M. SugYiama; H. KaJIGaya; M. UmedeA \& M. Isoda. 1985. Inflammatory reactions on Japanese quails muscular tissue caused by sutures. Bull. Nippon Vet. Zoot. Col. 31: 39-46.

Kajlgaya, H.; M. Kamekura; N. Tanaitara; A. Otha; H. Suzuki; M. Sugiyama \& M. Isoda. 1985. Acute and chronic inflammation induced by silk sutures in chicken mesentery. Bull. Nippon Vet. Zoot. Col. 34: 35-8.

Kori-Siakpere, O. 1985. Haematological characteristics of Clarias isheriensis Sydenham. Jour. Fish Biol. 27: 259-263.

Larsson, A.; M.J. Johansson-SJobeck \& R. FANGE. 1976. Comparative study of some haematological and biochemical blood parameters in fishes from Shagerrak. Jour. Fish Biol. 9: 425-440.

Lea Master, B.R.; J.A. Brock; R.S. Fujioka \& R.M. Nakamuras. 1990. Hematologic and blood chemistry values for Sarotherodon melanotheron and a red hybrid tilapia in freshwater and seawater. Comp. Biochem. Physiol. 97A (4): 525-529.

Lopes, R.; M.A. Sal.a; T. Paut.a-Lopfi; T.M.C. Ogasawara; L.S. Watanabe \& M. Sfmprini. 1997. Estudo hematológico de peixes brasileiros. XXXVII. As células sangüíneas do carapeba Diapterus rhombeus Valenciennes 1830 (Pisces, Gerridae), do Município de Iguape - SP, Brasil. Rev. Esc. Farm. Odont. Alfenas 19: 27-32.

LOWE-JiNDE, L. \& A.J. Nirmi. 1983. Influence of sampling on the interpretation of haematological measurements of rainbow trout, Salmo gairdneri. Can. Jour. Zool. 61: 396-402.

Martinez, F.J.; M.P. Garcia-Riera; M. Canteras; J. Costa \& S. Zamora. 1994. Blood parameters in Rainbow Trout (Oncorhynchus mykiss): Simultaneous influence of various factors. Comp. Biochem. Physiol. 107A: 95-100.

MATUSHIMA, E.R. \& M. M^RIANO. 1996. Kinetics of the inflammatory reaction induced by carrageenin in the swinbladder of Oreochromis niloticus (Nile tilapia). Braz. Jour. Vet. Anim. Sci. 33 (1): 5-10.

Murray, S.A. 1984. Hematological study of the bluegill, Lepomis macrochirus Raf. Comp. Biochem. Physiol. 78A (4): 787-791.

Penia, M.L,; J.L.C. Dias \& B.E. MALuCELli. 1996. Influence of low environmental temperature on the phagocytic activity of bullfrog (Rana catesbeiana) thrombocytes. Braz. Jour. Vet. Anim. Sci. 33 (1): $15-18$.

Pitombeira, M.S.; J.M. Martins \& E. Furtado. 1968. Hematology of the Atlantic thread herring, Opisthonema oglinum (Le Sueur). Arq. Est. Biol. Mar. Univ. Fed. Ceará 8 (2): 111-116.

RAIZADA, M.N. \& C.P. SiNGH. 1981. Seasonal variations in the differential leucocyte counts (DLC) of Cirrhinus mrigala (Ham). Indian Jour. Zoot. 22: 147-150.

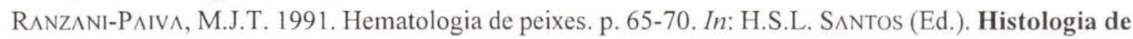
Peixes. São Paulo, FCAV-UNESP, 83p.

Ranzani-Paiva, M.J. 1996. Células sangüineas e contagem diferencial de leucócitos em 
pirapitinga-do-sul, Brycon sp., sob condições experimentais de criação intensiva. Rev. Ceres $\mathbf{4 3}$ (250): 685-695.

Ranzani-Paiva, M.J.; C.M. Ishikawa; M.C. Portella \& R.J. Celiberto. 1987. Hematologia da carpa comum Cyprinus carpio, infestada por Argulus sp. e após um tratamento com fosfato de 0,0-dimetil-oxi-2,2,2 - tricloroetilo (Neguvon). Bol. Inst. Pesca 14: 83-92.

Ranzani-Paiva, M.J.T.; F.A. Salles; J.C. Eiras; A.C. Eiras; C.M. Ishikawa \& A.C. Alexandrino. 1998/1999. Análise hematológica de curimbatá (Prochilodus scrofa), pacu (Piaractus mesopolamicus) e tambaqui (Colossoma macropomum) das estações de piscicultura do Instituto de Pesca, Estado de São Paulo. Bol. Inst. Pesca 25: 77-83.

RosenfEl.D, G. 1947. Corante pancrômico para hematologia e citologia clínica. Nova combinação dos componentes do May-Grunwald e do Giemsa num só corante de emprego rápido. Mem. Inst. Butantan 20: 329-334.

Silveira, R. \& C. Rigores. 1989. Caracteristicas hematologicas normales de Oreochromis aureus em cultivo. Rev. Lat. Acui 39: 54-56.

SUZUKI, K. 1986. Morphological and phagocytic characteristics of peritoneal exudate cells in tilapia, Oreochromis niloticus (Trewavas), and carp, Cyprinus carpio L. Jour. Fish Biol. 29 (3): 349-364.

TAVARES-Dias, M. \& C.D. Faustino. 1998. Parâmetros hematológicos da tilápia-do-Nilo Oreochromis niloticus (Cichlidae) em cultivo extensivo. Ars Veterinaria 14 (3): 254-263.

TAVARES-DiAs, M.; E.F.S. SANDrIM \& A. SANDRIM. 1998. Características hematológicas do tambaqui (Colossoma macropomum) Cuvier, 1818 (Osteichthyes: Characidae) em sistema de monocultivo intensivo. I. Série eritrocitária. Rev. Brasil. Biol. 58 (2): 197-202.

Tavares-Dias, M.; R.A. Tenani; L.D. Gioli \& C.D. Faustino. 1999a. Características hematológicas de teleósteos brasileiros. II. Parâmetros sangüíneos do Piaractus mesopotamicus Holmberg, 1887 (Osteichthyes: Characidae) em policultivo intensivo. Revta bras. Zool. 16 (2): 423-431.

Tavares-Dias, M.; E.F.S. SAndrim \& E. Campos-Filho. 1999b. Características hematológicas do tambaqui Colossoma macropomum Cuvier (Osteichthyes: Characidae) em sistema de monocultivo intensivo. II. Leucócitos. Revta bras. Zool. 16 (1): 175-184.

TAvares-Dias, M.; M.L. Martins \& S.N. KronKA. 1999c. Evaluation of the haematological parameters in Piaractus mesopotamicus Holmberg (Osteichthyes: Characidae) with Argulus sp. (Crustacea, Branchiura) infestation and treatment with organophosphate. Revta bras. Zool. 16 (2): 553-555.

Tavares-Dias, M; S.H.C. Schalch; M.L. Martins; E.D. Silva; F.R. Moraes \& D. Perecin. 1999d. Hematologia de teleósteos brasileiros com infecção parasitária. I. Varáveis do Leporinus macrocephalus Garavello \& Britski, 1988 (Anostomidae) e Piaractus mesopotamicus Holmberg, 1887 (Characidae). Acta Scientiarum 21 (2): 337-342.

Tavares-Dias, M; C.M.D. FrascÁ-Scorvo; F.R. Moraes; E. Campos-FILHO. 1999e. Características Hematológicas de Teleósteos Brasileiros. IV. Parâmetros Eritroleucométricos, Trombométricos e Glicemia do Matrinxã Brycon cephalus Günther, 1869 (Osteichthyes: Characidae). Ars Veterinária 15 (3): 149-153.

Weingerg, S.R.; C.D. Siegiel \& A.S. Gordon. 1973. Studies on the peripheral blood cell parameters and morphology on the red paradise fish, Macropodus opercularis. Effect of food deprivation on erythropoiesis. Anat. Rec. 175: 7-14.

Wintrobe, M.M. 1934. Variations on the size and hemoglobin content of erythrocytes in the blood various vertebrates. Fol. Haematol. 5: 32-49.

Z^NIBONI-FILHO, E. 1997. O desenvolvimento da piscicultura brasileira sem a deterioração da qualidade de água. Rev. Brasil. Biol. 57 (1): 3-9.

Recebido em 02.IX.1999; aceito em 26.IX.2000. 